\title{
Population structure and reproductive biology of Uca rapax (Decapoda: Ocypodidae) in a tropical coastal lagoon, southeast Brazil
}

\author{
Tarso Costa \& Abilio Soares-Gomes
}

\author{
Departamento de Biologia Marinha, Universidade Federal Fluminense. Caixa Postal 100644, 24001-970 Niterói, Rio de \\ Janeiro, Brasil.E-mail: tarsommc@yahoo.com.br; abiliosg@vm.uff.br
}

\begin{abstract}
A population of the fiddler crab Uca rapax (Smith, 1870) found in Itaipu Lagoon, southeast Brazil, was sampled monthly from July 2006 to June 2007 in order to study population and reproductive features. The sex ratio of the population was statistically different from the expected $(1: 1)$ in almost every month, with a predominance of males. The reproductive cycle and the recruitment of juveniles were continuous, with two peaks. The fecundity ranged from 1.110 to 13.189 eggs $(4.984 \pm 2.493 .8)$, not differing statistically among seasons. In contrast, the relative fecundity ( $\left.F^{\prime}\right)$ and the reproductive intensity index (RII) were highest in the summer. Female size at the onset of sexual maturity was estimated as $6.1 \mathrm{~mm}$ and egg diameter ranged from 0.20 to $0.28 \mathrm{~mm}$. The anthropogenic impact on the environment of Itaipu Lagoon probably had adverse effects on the local U. rapax population, as inferred by its low fecundity rates, early maturation age and biased sex ratio.
\end{abstract}

KEY WORDS. Fiddler crab; fecundity; reproduction; sex ratio.

The Uca (Leach, 1814) crabs, known as fiddler crabs, are widely distributed in the tropics and subtropics. They live in intertidal zones of protected bays, lagoons, estuaries and riverbanks, burrowing in the sediment, and feeding on deposit organic matter (CRANE 1975). Their digging activity causes bioturbation that plays an important role in nutrient cycling, improving the transfer of material to nearby ecosystems (COLBY \& FonseCA 1984, Genoni 1991). They are part of the diet of several species of fishes, birds, mammals and other crabs, being important items in intertidal food webs (KocH et al. 2005, MASUNARI 2006)

Decapod crustaceans have a wide range of reproductive patterns that emerges from adaptive processes, leading to population maintenance. According to HARTNOLL \& Gould (1988), variability in crustacean reproductive pattern is an adaptive process determined by evolutionary pressures to increase progeny survival. Fertility and type of reproductive cycle, among other variables, regulate the size of animal populations. Information about reproductive patterns helps the understanding of adaptive strategies and reproductive potential of different species (Castiglioni \& Negreiros-Fransozo 2006b).

Fecundity is an important parameter of reproductive strategy (SASTRY 1983). It is measured as the number of eggs produced per ovigerous female and is an important parameter when estimating the reproductive potential and future stock size of a given species or population (HatTori \& PinheIro 2003). Therefore, fecundity analyses are not only an estimate of egg number average, but also a representation of the rhythm associated with the reproductive cycle.
Uca rapax (SмIтн 1870) inhabits mud and muddy-sand galleries in tropical and subtropical regions. It has a wide geographic range, occurring from Florida to Brazil (Melo 1996). The wide geographic range of this species is probably related to its great tolerance and plasticity to critic environmental variations (mainly salinity stresses and desiccation), which allow the occupation of a large spectrum of habitats (ZANDERS \& ROJAS 1996b, Castiglioni \& Negreiros-Fransozo 2006a).

Many aspects of the behavior, physiology, growth and populational biology of this species are well known (SALMON 1971, Greenspan 1980, McNamara \& Moreira 1983, Genoni 1985, 1991, Salmon \& KetTler 1987, Zanders \& Rojas 1996a, b, c, Castiglioni \& Negreiros-Fransozo 2004, 2005), but little information is available on its reproduction (CASTIGLIONI \& NEgREIROS-Fransozo 2006a, b, c, CAstiglioni et al. 2008, Figueiredo et al. 2008).

In the present work, some aspects of population and reproductive biology of $U$. rapax, such as sex ratio, fecundity, reproductive period, juvenile recruitment and size at onset of sexual maturity of females were studied in order to: a) assess the such population features for this fiddler-crab in a little stand mangrove located in a tropical costal lagoon with a high anthropic interference; b) compare the present data with populations of this and other congeneric species in different habitats and/or latitudes.

\section{MATERIAL AND METHODS}

The Itaipu Lagoon $\left(22^{\circ} 55^{\prime} \mathrm{S}, 43^{\circ} 03^{\prime} \mathrm{W}\right.$, Fig. 1$)$ belongs to a set of coastal lagoons on the east coast of the state of Rio de Janeiro, southeast Brazil. This lagoon is connected to Piratininga 


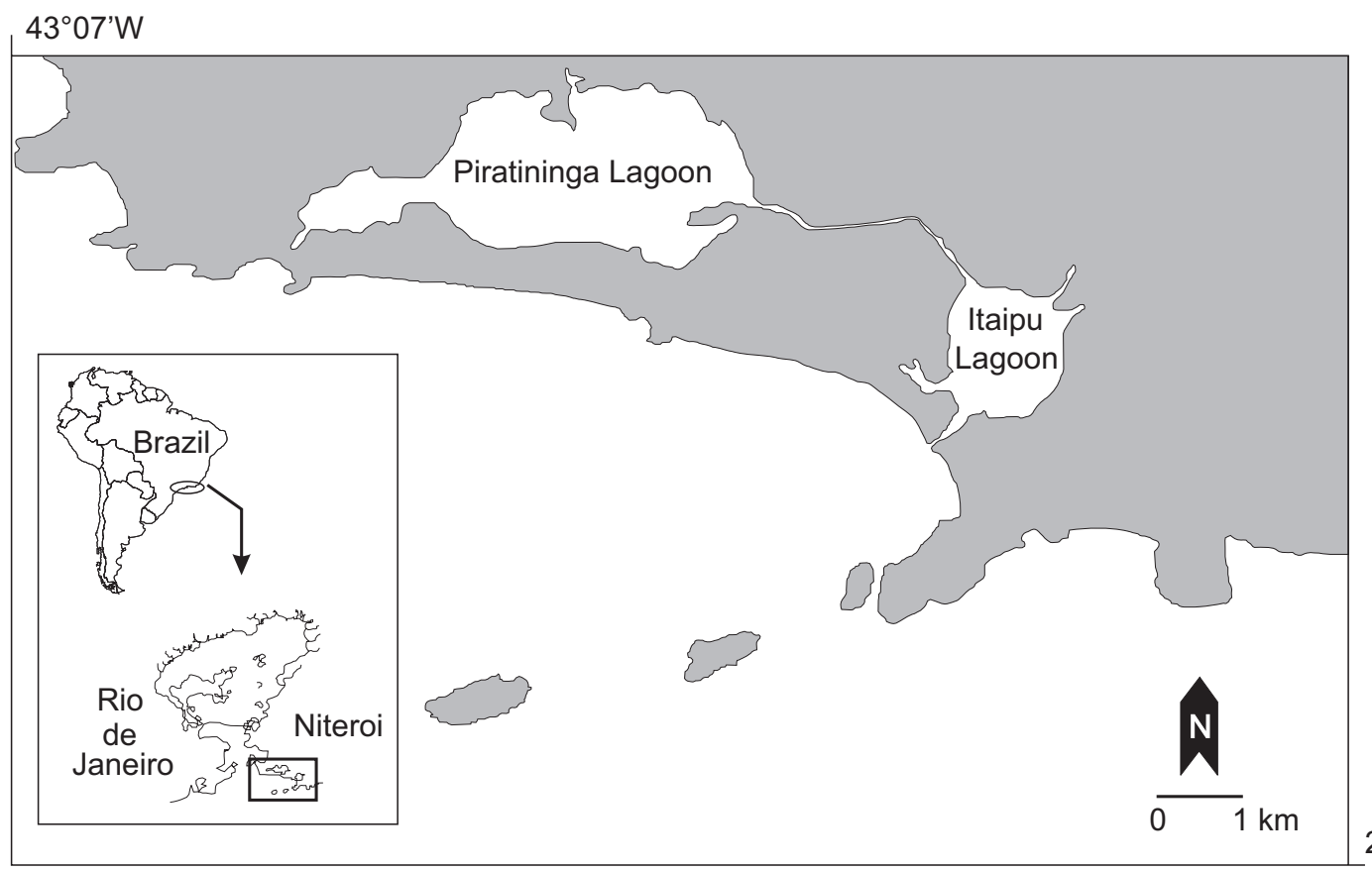

Figure 1. Location of Itaipu Lagoon.

Lagoon by a restricted $2.4 \mathrm{~km}$ long channel. Itaipu Lagoon is connected to the sea by a narrow and shallow canal. The size of this lagoon is relatively small, with $2 \mathrm{~km}^{2}$ of surface area, and mean water depth of $1.2 \mathrm{~m}$ with mean tidal range of 30 $\mathrm{cm}$. Salinity can reach close to 30 PSU and the flushing halflife is one day, with quick water exchange with the sea via a tidal channel (KJERFVE \& KNOPPERS 1999).

Untreated domestic effluent input, deforestation of marginal habitats, and landfills are the main anthropogenic actions in the area.

Crabs were collected on a monthly basis, from July 2006 to June 2007, by digging the sediment enclosed in five $0.25 \mathrm{~m}^{2}$ areas, with a spade, at low tide in the muddy-sand sediment of a small mangrove stand of Laguncularia racemosa (GAERTEN 1807). Individuals were sexed according to the morphology of the abdomen. Monthly, the chi-square test $\left(\chi^{2}\right)$ was performed to assess significant deviations of the $1: 1$ sex ratio $(p<0.05)$. Carapace width (CW) was measured to the nearest $0.01 \mathrm{~mm}$ with a digital vernier caliper and individuals were grouped into $10 \mathrm{CW}$ classes of $2.0 \mathrm{~mm}$. Crabs of both sexes with CW smaller than the smallest ovigerous female observed were classified as juveniles (Koch et al. 2005, Litulo 2006).

The period of time when ovigerous females were found in the population was referred to as the breeding season and was used to estimate the reproductive period over the sampling period (Litulo 2004, Leme 2006). The size of females at onset of sexual maturity was calculated based on the percentage of mature females by CW classes. The logistic adjustment, where the size at which $50 \%$ of the females $\left(\mathrm{CW}_{50 \%}\right)$ are mature, represents the size at onset of sexual maturity (Muiño et al. 1999, КосH et al. 2005).

Monthly fecundity was estimated by counting eggs by the volumetric method, using a total volume of $30 \mathrm{ml}$ and subsamples of $1 \mathrm{ml}$ (Díaz et al. 1983, Сово \& Fransozo 2003). Oneway ANOVA was employed, before testing the normality and variance homogeneity assumptions, to compare fecundity across seasons.

The ovigerous female percentage (OP\%) was calculated for each month. Relative fecundity $\left(F^{\prime}\right)$, eliminating the size effect, was calculated for each season by the formula $\mathrm{F}^{\prime}=1 / \mathrm{n} \Sigma \mathrm{EN} / \mathrm{CW}^{\mathrm{b}}$ (Pinheiro \& Terceiro 2000), where $n$ is the number of ovigerous females in the month or season, EN the egg number, CW the carapace width and $b$ the angular coefficient of power function in the EN/CW relationship. The reproductive intensity index (RII) was also calculated for each season by multiplying OP\% times F' (Pinheiro \& Terceiro 2000).

Twenty eggs from each ovigerous females were randomly picked up to measure egg diameter under a stereomicroscope coupled with a millimeter scale. Three stages of embryonic development were characterized: Stage I (initial) - freshly extruded egg mass sponge with an orange colour due to a large quantity of yolk, no signs of segmentation and the egg appears as a ball of cells.; Stage II (intermediate) - incubation at its halfway period, the sponge has a light brown colour tending to grey, the compound eyes of the larvae are visible and the embryo occupies 1/3 of the volume of the egg.; Stage III (final) 
- the larvae are a few days from eclosion and are totally formed, the sponge is dark brown tending to black and little yolk is left (Litulo 2005a). One-way ANOVA was performed to compare the size among the three stages $(\alpha=0.05)$.

The crabs were classified in five molt stages according Castiglioni \& Negreiros-Fransozo (2006b): a) recent post-molt flexible carapace without calcification; b) advanced post-molt begining of the calcification, breaking carapace, but more resistent; c) intermolt - carapace totally calcificated with hard consistency; d) pre-molt - presence of a new exoeskeleton internally to the oldest and appearing of molting lines in the pterigostomial region; e) molt - exactly moment of the change or the leaving of the crab to the old exoeskeleton. The molt stagies were agruped in recent molt (a, b, d and e) and intermolt (c). The molt activity was analised over the year seasons and by CW classes.

\section{RESULTS}

A total of 915 crabs, 530 males and 385 females (76 ovigerous), were sampled during the study period. The males, females and ovigerous females were most frequent in the 10.0-12.00 mm CW class (Fig. 2). The CW of males (mean \pm SD: $10.43 \pm 2.64$ ) was statistically different from the females (mean \pm SD: $9.42 \pm 2.45$ ) (Student's t-test $=5.68, \mathrm{p}<0.05$ ). In all months except for January, May and June 2007, the sex ratio was statistically different from the expected (1:1), males being more frequent than females (Tab. I).

Figure 3 shows the monthly frequency of ovigerous females and juveniles. In relation to monthly frequency $(n=76)$, ovigerous females occurred throughout the entire sampling period, being most frequent in October 2006 and March and April 2007, indicating continuous breeding. Juveniles were most abundant in July 2006 and January and June 2007. CW of the smallest ovigerous female was $7.85 \mathrm{~mm}$ and the size at onset of

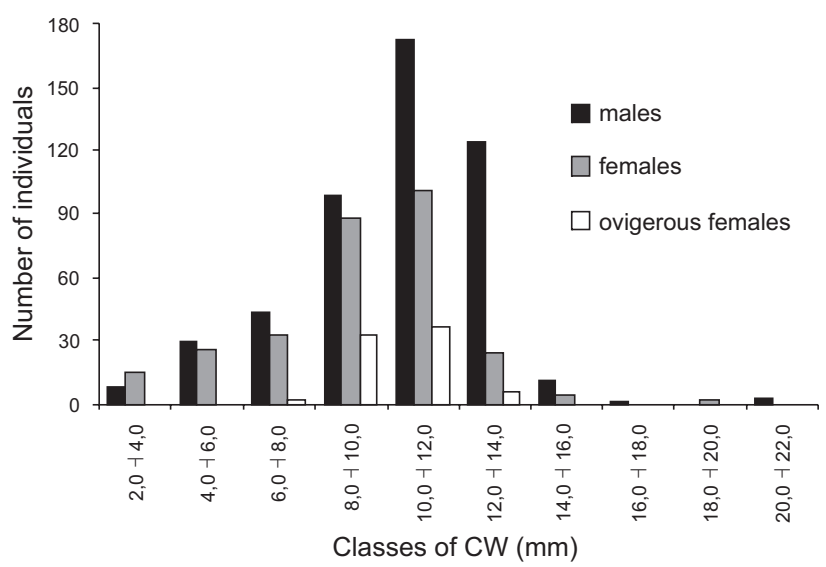

Figure 2. Absolute frequency of males, females and ovigerous females in each CW class of $U$. rapax from Itaipu Lagoon.

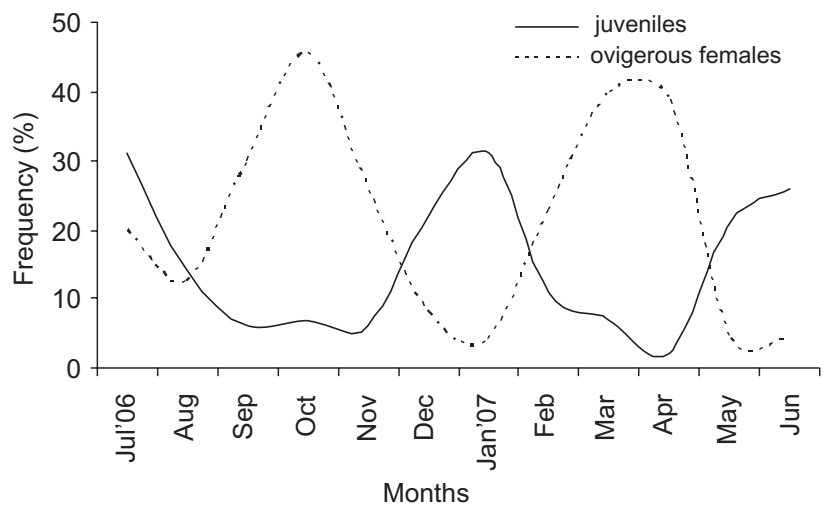

Figure 3. Monthly frequency of ovigerous females and juveniles of $U$. rapax from Itaipu Lagoon.

Table I. Number of adult males and females, number of juveniles, sex ratio and population density by month of $U$. rapax from Itaipu Lagoon. $\left(^{*}\right)$ Significant deviations of the $1: 1$ proportion to sex ratio $(p<0.05)$.

\begin{tabular}{lccccccccc}
\hline \multicolumn{1}{c}{ Months } & Adult males & Juvenile males & Total & Adult females & Juvenile females & Total & Sex ratio (M:F) & Chi square test $\left(^{*}\right)$ \\
\hline July 2006 & 36 & 19 & 55 & 17 & 13 & 30 & $1.83: 1$ & $7.278^{*}$ \\
August & 29 & 7 & 36 & 25 & 7 & 32 & $1.12: 1$ & $0.234^{*}$ \\
September & 67 & 6 & 73 & 28 & 0 & 28 & $2.60: 1^{*}$ & $19.144^{*}$ \\
October & 39 & 5 & 44 & 20 & 2 & 22 & $2: 1$ & $7.332^{*}$ \\
November & 38 & 4 & 42 & 29 & 2 & 31 & $1.35: 1$ & $1.694^{*}$ \\
December & 26 & 11 & 37 & 14 & 11 & 25 & $1.48: 1$ & $2.322^{*}$ \\
January 2007 & 37 & 12 & 49 & 27 & 19 & 46 & $1.06: 1$ & 0.103 \\
February & 36 & 8 & 44 & 29 & 3 & 32 & $1.37: 1$ & $2.21^{*}$ \\
March & 33 & 3 & 36 & 21 & 4 & 25 & $1.44: 1$ & $2.033^{*}$ \\
April & 36 & 0 & 36 & 29 & 2 & 31 & $1.16: 1$ & $0.381^{*}$ \\
May & 24 & 11 & 35 & 25 & 10 & 35 & $1: 1$ & 0 \\
June & 33 & 10 & 43 & 32 & 16 & 48 & $0.89: 1$ & 0.288 \\
\hline Total & 434 & 96 & 530 & 296 & 89 & 385 & $1.37: 1$ & $22.94^{*}$ \\
\hline
\end{tabular}


maturity estimated was $\mathrm{CW}_{50 \%}=6.1 \mathrm{~mm}$ (Fig. 4). This measure represents $33.8 \%$ of the $\mathrm{CW}$ observed in the largest ovigerous female sampled.

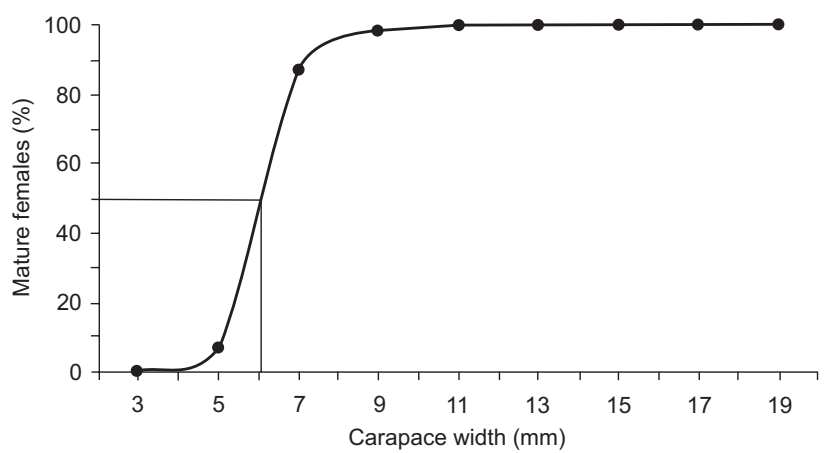

Figure 4. Size at onset of sexual maturity of females $\left(\mathrm{CW}_{50 \%}\right)$ of $U$. rapax from Itaipu Lagoon.

Fecundity ranged from 1.110 to 13.189 eggs (mean \pm SD: $4.984 \pm 2.493 .8)$, not differing among the seasons $(F=0.382$, $\mathrm{p}>0.05$ ) (Fig. 5). The number of eggs was correlated with the size, increasing in the largest CW classes (Fig. 6). F' ranged from 4.4 to 405.3 and RII from 94.3 to 7052.2 , with both the maximum and the minimum values occurring in the summer and winter, respectively (Tab. II).

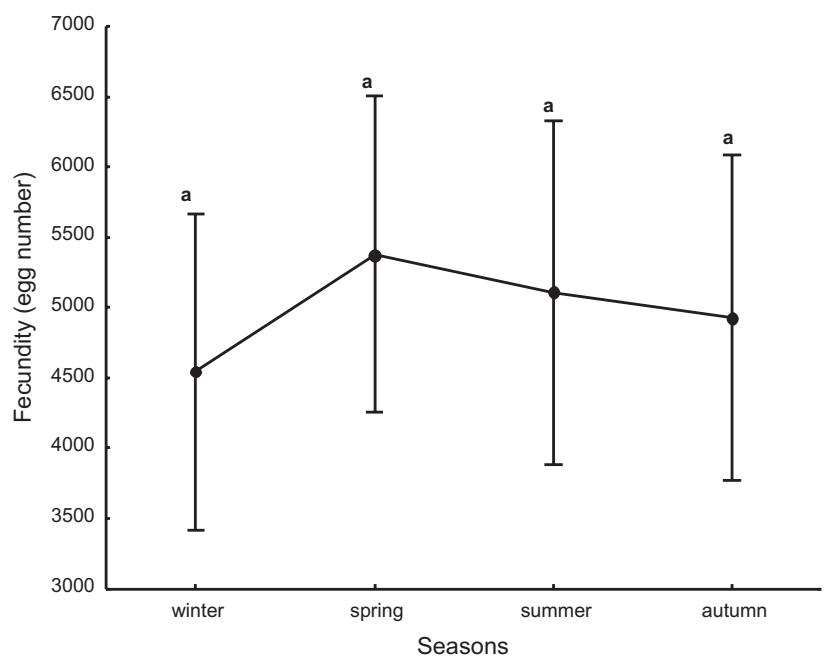

Figure 5. Variation of fecundity along seasons of $U$. rapax from Itaipu Lagoon. Equal letters shows no statistical difference ( $p>0.05)$.

Egg diameter ranged from 0.2 to $0.28 \mathrm{~mm}$ (mean $\pm \mathrm{SD}$ : $0.24 \pm 0.01 \mathrm{~mm})$. The size of stage I was significantly smaller than stages II and III ( F = 5.04; $\mathrm{p}<0.05)$ (Tab. III). The initial stage was also the most frequent over the sampling period (Fig. 7).

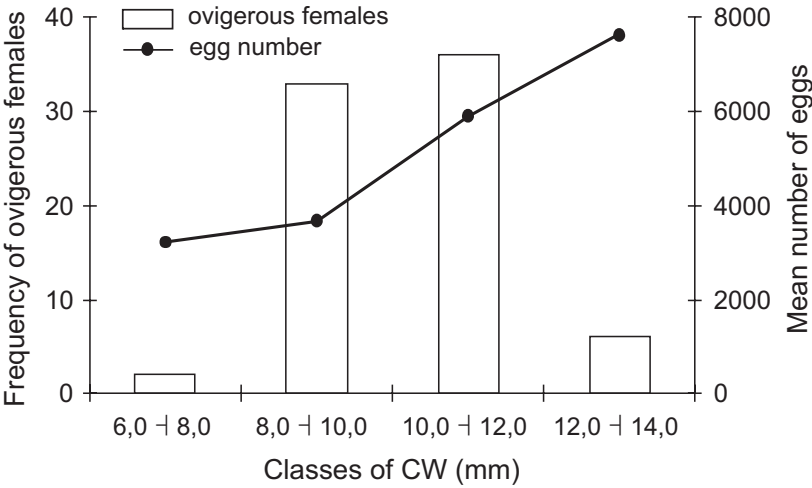

Figure 6. Number of eggs and frequency of ovigerous females in each CW class of U. rapax from Itaipu Lagoon.

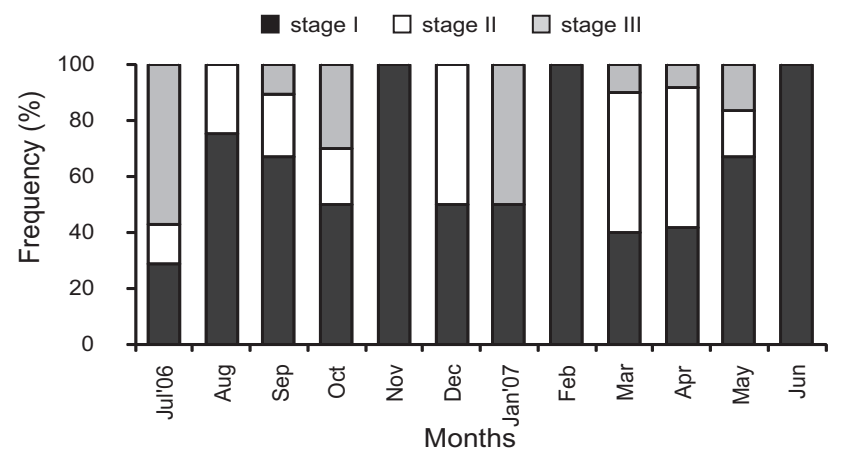

Figure 7. Monthly variation in frequency of embryo stages of ovigerous females of $U$. rapax from Itaipu Lagoon.

The frequency of crabs in molt activity over the sample period was smallest (26\%) than the frequency of intermolt crabs $(\mathrm{p}<0.05)$. Along the seasons, intermolt crabs were also most frequent than those in molt activity $(\mathrm{p}<0.05)$ (Fig. 8). Within $\mathrm{CW}$ classes, males in intermolt occurred in the second class, whereas the females occured in the third one.

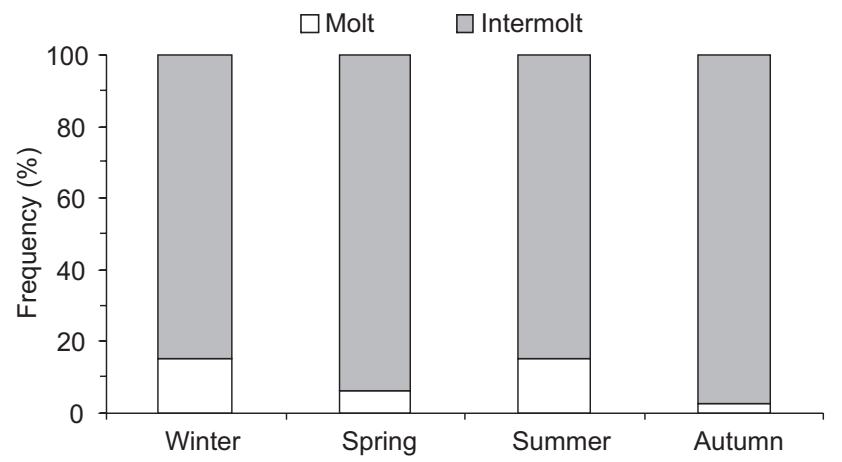

Figure 8. Frequency of $U$. rapax in molt activity and in intermolt by seasons from Itaipu Lagoon. The asteristics shows significant differences $(p<0.05)$. 
Table II. Relative fecundity $\left(\mathrm{F}^{\prime}\right)$, reproductive intensity index (RII) and percentage of ovigerous females (OP) by season of $U$. rapax from Itaipu Lagoon.

\begin{tabular}{lcccrrrr}
\hline \multicolumn{1}{c}{ Seasons } & Juvenile females & Non-ovigerous adult females & Adult females & Total & \multicolumn{1}{c}{ OP\% } & $F^{\prime}$ & \multicolumn{1}{c}{ RII } \\
\hline Winter & 20 & 51 & 19 & 90 & 21.1 & 4.4 & 94.3 \\
Spring & 15 & 43 & 20 & 78 & 25.6 & 56.3 & 1441.2 \\
Summer & 26 & 59 & 18 & 103 & 17.4 & 405.3 & 7052.2 \\
Autumn & 28 & 66 & 20 & 114 & 17.5 & 91.1 & 1594.2 \\
\hline Total & 89 & 219 & 77 & 385 & 20.0 & - \\
\hline
\end{tabular}

Table III. Variation of egg diameter for each embryo stage of $U$. rapax from Itaipu Lagoon. Equal letters show no statistical difference $(\mathrm{p}>0.05)$.

\begin{tabular}{lccccc}
\hline \multirow{2}{*}{ Embryonic stage } & $\mathrm{n}$ & \multicolumn{4}{c}{ Egg diameter $(\mathrm{mm})$} \\
\cline { 3 - 6 } & & Minimum & Maximum & Average & Standard deviation \\
\hline Initial & 35 & 0.200 & 0.285 & $0.237 \mathrm{a}$ & 0.017 \\
Intermediate & 12 & 0.236 & 0.267 & $0.250 \mathrm{~b}$ & 0.010 \\
Final & 10 & 0.228 & 0.265 & $0.251 \mathrm{~b}$ & 0.012 \\
\hline
\end{tabular}

\section{DISCUSSION}

The different reproductive strategies of decapod crustaceans are the result of a coordinated action of exogenous (e.g. temperature, food availability) and endogenous factors (e.g. gonad development period, eggs incubation duration and releasing of larvae, age of attaining sexual maturity). These factors exert influence on behavior, maturity, fecundity and reproductive period in fiddler crabs populations (SASTRY 1983). The temperature at Itaipu Lagoon seems to favor adequate conditions over all year long to social behavior, feeding, gonadal maturation and egg incubation. However, other features of this coastal lagoon seem to have critical influences on the fiddler crabs. The mangrove stand where they live may not supply adequate amount of food because it is very small and little productive. Furthermore, the small size of the mangrove does not provide shadow for crabs during exposure to critical temperatures in the warmest periods of the day, given that the crabs remain much time enclosed in the burrows in order to prevent desiccation. As a result, less time is dedicated to agonistic behavior and/or feeding (TEAL 1958). The intense presence of tourists (mainly in the summer) and the high salinity of the Itaipu Lagoon are also stressful conditions for this population.

Females smaller than males are known for many other fiddler crab populations, such as Uca leptodactyla Rathbun, 1898 (Masunari \& Swiech-Ayoub 2003), U. rapax Smith, 1870 (Castiglioni \& Negreiros-Fransozo 2004), U. annulipes H. Milne Edwards, 1837, U. inversa Hoffmann, 1874 (Litulo 2005a, b) and U. lactea annulipes $\mathrm{H}$. Milne Edwards, 1852 (MohKTARI et al. 2008). This difference in size could indicate that females invest less energy in body growth, transferring greater amount of energy to reproductive processes, such as gonadal maturation, and the production and development of eggs. (CASTIGLIONI \& Negreiros-Fransozo 2006c). Males, in turn, may use most of their energy for body growth and growth of the major chelipod, becoming attractive for females and more capable of succeeding in intraspecific competitions with other males, thereby increasing their chance of mating with one or more female.

The deviation of sex ratio from the expected (1:1) in almost all months in the present work, with predominance of males, was also encountered by MOHкTARI et al. (2008) U. lactea H. Milne Edwards, 1852, Colpo \& Negreiros-Fransozo (2003) $U$. vocator Herbst, 1804, КосH et al. (2005) U. cumulanta Crane, 1943 and $U$. rapax. This is not in line with other populations of fiddler crabs studied, such as U. annulipes (Litulo 2004, 2005a), $U$. maracoani Latreille, 1802, U. vocator (КосH et al. 2005), $U$. chlorophtalmus H. Milne Edwards, 1837 (Litulo 2006), U. thayeri Rathbun, 1900 (BezerRa \& Matthews-CasCón 2008) and U. rapax (Castiglioni \& Negreiros-Fransozo 2006a), with significant deviations observed only in few months. According to Werner (1972), in mature marine crustaceans, a deviation from the expected 1:1 sex ratio seems to be the rule rather than the exception. In the present study, there was no indication for sexspecific distribution or for reduced catchability of females, factors that can increase the sex selectivity. Therefore, other features of the population biology of fiddler crabs may account for the observed male-biased sex ratio, such as differential growth, different maximum sizes and mortality rates (MOHKTARI et al. 2008). Differences in the biology among the sexes, such as differential investment in the reproductive process, survival in the recruitment and exposure to predators seem to explain the male biased proportion (Ayres-Peres \& Mantelatto 2008). 
The latter is linked to the sexual dimorphism of fiddler crabs. Male crabs, because of the large size of one of their chelipeds, have more success in escaping from predators than do the females. Due to those morphological differences, males can shed their large claw when attacked and have a higher chance of escaping from predators, thus increasing their survival $(\mathrm{KoCH}$ et al. 2005). In Itaipu Lagoon, the possibility of predation by birds is high all year around. Male-biased sex ratio, according to Ayres-Peres \& Mantelatto (2008), can be a strategy of fiddler crabs, enabling females to copulate with several males along the reproductive process. In such way, retaining greater amounts of sperm, the females can produce new oocyts without copulating, decreasing expenses with energy and predation risk (Leme 2006). Geisel (1972) points out that sex ratio imbalance is typical of fiddler-crab populations that live in unstable environments (such as Itaipu Lagoon, which suffers high anthropic influence), because the animals are not behaviorally or physiologically adapted to such environments.

The reproductive cycle of $U$. rapax in Itaipu Lagoon, as in other species of this genus occurring in Brazil, was continuous, with peaks during the spring and autumn. The occurrence of a more prolonged reproductive cycle in species living in the tropics and subtropics is commonly related to the permanent availability of food, and benign environmental conditions that do not constrain gonadal development or larval release (Castiglioni \& Negreiros-Fransozo 2006b). In temperate species, the low temperature is the main factor responsible for a shorter reproductive period, in some cases promoting hibernation, which stops or slows gonadal development (Crane 1975). Temperate zone species reduce their metabolism in the coldest seasons, as verified by VeRnBERG (1959), by recording their oxygen consumption. Therein, the author concluded that the U. rapax population inhabiting the temperate zone of Florida consumes less oxygen when temperature decreases at significant levels. On the other hand, the tropical population of U. rapax from Jamaica, in the same work, did not differ significantly the metabolic rate along the year in response to constant temperature all year round. In temperate populations, when the temperature decreases below certain level, the crabs change their behavior and less time is allocated for foraging and sexual activities. Therefore, the crabs are not provided with sufficient energy for reproduction and remain reclused in their burrows. Moreover, gonadal development is also directly related to temperature. It works as a catalytic agent, accelerating processes that lead to the formation of gonadal tissues and its maturation (Lima et al. 2006). For THorson (1950), pelagic conditions favorable for larval release are the key factor for the maintenance of a continuous reproductive cycle in marine organisms. Ideal food availability and temperature for the larvae means less time spent living in the plankton, due to its faster development, which diminishes the high risk of predation represented by the planktonic phase. Due to favorable environmental conditions over the year, populations of fiddler crabs that live in tropics and subtropics tend to have a wider reproductive period in comparison with those that live in temperate regions (Tab. IV). A continuous recruitment should be the result of the continuous hatching and also of the favorable conditions over all year for the planktonic larval development, characteristic of tropical regions. Occurrence of juveniles is more intensive in months after high reproductive activity, as may be seen by the shift between reproduction and recruitment peaks (Fig. 2).

Comparing the size at onset of sexual maturity estimated for the $U$. rapax females in Itaipu Lagoon $\left(\mathrm{CW}_{50 \%}=6.1 \mathrm{~mm}\right)$ with the other sizes calculated for the same species in other localities of Brazil, it may be supposed that this population attains maturity precociously (Tab. V). The size at which fiddler crabs attain sexual maturity is influenced by food availability, population density, temperature or the interaction of these factors (Castiglioni \& Negreiros-Fransozo 2006c; Bezerra \& MatThews-CASCON 2008). In the present study, the population of $U$. rapax does not inhabit a typical mangrove area and, because the low productivity of the mangrove stand, it does not make use of a rich and abundant food source. The aforementioned environmental characteristics probably contribute the most to the early maturity in this population.

Concerning fecundity, the number of eggs produced is species-specific, varying widely in relation to latitude, habitat structure, and food availability (Hemni 2003). In Brazil, ColPo \& Negreiros-Fransozo (2003) and Castiglioni \& Negreiros-Fransozo (2005) observed that the fecundity also varies between populations of the same fiddler-crab species that inhabit sites with distinct environmental conditions in different latitudes, even in narrow latitudinal gradients, suggesting the interference of habitat in the brood size. The average estimated fecundity for $U$. rapax in the present study $(4,984$ eggs) is much smaller than that estimated by GrEensPan (1980) (28,500 eggs). The low fecundity of $U$. rapax in Itaipu Lagoon could be a consequence of the harsher environmental conditions that induce reduced population growth (mainly because the low food supply), leading to a small fecundity. Given that the size of the crab determines, in part, the number of eggs, the fecundity is lower in those cases. Therefore, fecundity and animal size in those crabs are directly correlated, with larger females exhibiting larger broods than smaller ones (Hines 1982, HarTNOLL 1985). According to Henmi (1989), ovigerous females of fiddler crabs, which do not stay inside their burrows and emerge up to the sediment to feed, get sufficient energy to produce larger broods than those that stay in their burrows. On the other hand, egg loss is higher than it would be if they remained inside their burrows, without the risk of desiccation and exposing eggs to stressful conditions. In this study, the reduced growth and the small number of eggs produced seems to be the most reasonable explanation, given that none of the ovigerous females were seen outside their burrows. Uca rapax in Itaipu Lagoon produces small broods over all year. Females with eggs in all embrionary stages were included in the method employed to 
Table IV. Reproductive period of fiddler-crab species from different localities.

\begin{tabular}{|c|c|c|c|}
\hline Species & Locality & Season & Author \\
\hline \multirow[t]{2}{*}{ U. pugilator } & North Carolina, EUA & spring-summer & Colby \& FonseCA (1984) \\
\hline & $34^{\circ} 43^{\prime} 14^{\prime \prime} \mathrm{N}, 76^{\circ} 39^{\prime} 9^{\prime \prime} \mathrm{W}$ & & \\
\hline \multirow[t]{2}{*}{ U. thayeri } & Florida, EUA & spring-summer & SALMON (1987) \\
\hline & $27^{\circ} 26^{\prime} 19^{\prime \prime} \mathrm{N}, 80^{\circ} 20^{\prime} 7^{\prime \prime} \mathrm{W}$ & & \\
\hline \multirow[t]{2}{*}{ U. uruguaiensys } & Chiquita Sea, Argentina & spring-summer & SPIVAK et al. (1991) \\
\hline & $30^{\circ} 30^{\prime} \mathrm{S}, 62^{\circ} 40^{\prime} \mathrm{W}$ & & \\
\hline \multirow[t]{2}{*}{ U. annulipes } & Mgazana, South Africa & summer-autumn & EMMERSON (1994) \\
\hline & $32^{\circ} 4^{\prime} \mathrm{S}, 28^{\circ} 45^{\prime} \mathrm{E}$ & & \\
\hline \multirow[t]{2}{*}{ U. clorophthalmus } & Mgazana, South Africa & spring-summer & EMMERSON (1994) \\
\hline & $32^{\circ} 4^{\prime} \mathrm{S}, 28^{\circ} 45^{\prime} \mathrm{E}$ & & \\
\hline \multirow[t]{2}{*}{ U. urvillei } & Mgazana, South Africa & summer-autumn-winter & EMMERSON (1994) \\
\hline & $32^{\circ} 4^{\prime} \mathrm{S}, 28^{\circ} 45^{\prime} \mathrm{E}$ & & \\
\hline \multirow[t]{2}{*}{ U. vocans } & Mgazana, South Africa & spring-summer-autumn & EMMERSON (1994) \\
\hline & $32^{\circ} 4^{\prime} \mathrm{S}, 28^{\circ} 45^{\prime} \mathrm{E}$ & & \\
\hline \multirow[t]{2}{*}{ U. tangeri } & Cadiz Bay, Spain & spring-summer & RodríGuez et al. (1997) \\
\hline & $36^{\circ} 32^{\prime} \mathrm{N}, 6^{\circ} 18^{\prime} \mathrm{W}$ & & \\
\hline \multirow[t]{2}{*}{ U. vocator } & Ubatuba, Brazil & all year & Colpo \& NeGreiros-Fransozo (2003) \\
\hline & $23026^{\prime} 02^{\prime \prime} \mathrm{S}, 45004^{\prime} 15^{\prime \prime} \mathrm{W}$ & & \\
\hline \multirow[t]{2}{*}{ U. annulipes } & Sun Coast, Mozambique & all year & Litulo (2004) \\
\hline & $25^{\circ} 57^{\prime} \mathrm{S}, 32^{\circ} 35^{\prime} \mathrm{E}$ & & \\
\hline \multirow[t]{2}{*}{ U. rapax } & Caeté estuary, Brazil & all year & KocH et al. (2005) \\
\hline & $01^{\circ} 03^{\prime} 46^{\prime \prime} \mathrm{S}, 46^{\circ} 46^{\prime} 22^{\prime \prime} \mathrm{W}$ & & \\
\hline \multirow[t]{2}{*}{ U. inversa } & Sun Coast, Mozambique & all year & Litulo (2005a) \\
\hline & $25^{\circ} 57^{\prime} \mathrm{S}, 32^{\circ} 35^{\prime} \mathrm{E}$ & & \\
\hline \multirow[t]{2}{*}{ U. urvillei } & Sun Coast, Mozambique & all year & Litulo (2005b) \\
\hline & $25^{\circ} 57^{\prime} \mathrm{S}, 32^{\circ} 35^{\prime} \mathrm{E}$ & & \\
\hline \multirow[t]{2}{*}{ U. thayeri } & Ubatuba, Brazil & spring-summer & Costa et al. (2006) \\
\hline & $23^{\circ} 26^{\prime} 02^{\prime \prime} \mathrm{S}, 45^{\circ} 04^{\prime} 15^{\prime \prime} \mathrm{W}$ & & \\
\hline \multirow[t]{2}{*}{ U. uruguayensis } & Ubatuba, Brazil & all year & Costa et al. (2006) \\
\hline & $23^{\circ} 26^{\prime} 02^{\prime \prime} \mathrm{S}, 45^{\circ} 04^{\prime} 15^{\prime \prime} \mathrm{W}$ & & \\
\hline \multirow[t]{2}{*}{ U. clorophthalmus } & Inhaca Island, Mozambique & all year & LITULO (2006) \\
\hline & $26^{\circ} 00^{\prime} 17^{\prime \prime} \mathrm{S}, 32^{\circ} 54^{\prime} 52^{\prime \prime} \mathrm{E}$ & & \\
\hline \multirow[t]{2}{*}{ U. rapax } & Ubatuba, Brazil & all year & Castiglioni \& Negreiros-Fransozo (2006b) \\
\hline & $23^{\circ} 26^{\prime} 02^{\prime \prime} \mathrm{S}, 45^{\circ} 04^{\prime} 15^{\prime \prime} \mathrm{W}$ & & \\
\hline \multirow[t]{2}{*}{ U. rapax } & Paraty, Brazil & all year & Castiglioni \& Negreiros-Fransozo (2006a) \\
\hline & $23^{\circ} 26^{\prime} 02^{\prime \prime} \mathrm{S}, 45^{\circ} 04^{\prime} 15^{\prime \prime} \mathrm{W}$ & & \\
\hline \multirow[t]{2}{*}{ U. lactea annulipes } & Sirik mangrove, Iran & spring-summer & MoHKTARI et al. (2008) \\
\hline & $26^{\circ} 30^{\prime} 51^{\prime \prime} \mathrm{N}, 57^{\circ} 6^{\prime} 24^{\prime \prime} \mathrm{E}$ & & \\
\hline \multirow[t]{2}{*}{ U. rapax } & Niterói, Brazil & all year & This study \\
\hline & $22^{\circ} 52^{\prime} 58^{\prime \prime} \mathrm{S}, 43^{\circ} 06^{\prime} 14^{\prime \prime} \mathrm{W}$ & & \\
\hline
\end{tabular}


Table V. Size at onset of sexual maturity in U. rapax from different localities in Brazil.

\begin{tabular}{|c|c|c|c|c|}
\hline Locality & Sex & $\begin{array}{l}\text { Size at onset of sexual } \\
\text { maturity }(\mathrm{mm}(\mathrm{CW}))\end{array}$ & Method & Author/year \\
\hline \multirow[t]{2}{*}{ Ubatumirim Mangrove, Ubatuba } & M & 13.5 & relative growth & Casticlioni \& NeGreiros-Fransozo (2004) \\
\hline & $\mathrm{F}$ & 11.2 & & \\
\hline \multirow[t]{2}{*}{ Itamambuca Mangrove, Ubatuba } & M & 15.2 & relative growth & Castiglioni \& Negreiros-Fransozo (2004) \\
\hline & $\mathrm{F}$ & 12.1 & & \\
\hline Caeté Estuary, Bragança & $\mathrm{F}$ & 8.0 & smallest ovigerous female & Косн et al. (2005) \\
\hline \multirow[t]{2}{*}{ Paraty, Rio de Janeiro } & M & 14.1 & gonadal stages & Castiglioni \& Negreiros-Fransozo (2006a) \\
\hline & $\mathrm{F}$ & 10.95 & & \\
\hline \multirow[t]{2}{*}{ Ubatumirim Mangrove, Ubatuba } & M & 13.6 & gonadal stages & Castiglioni \& Negreiros-Fransozo (2006c) \\
\hline & $\mathrm{F}$ & 11.4 & & \\
\hline \multirow[t]{2}{*}{ Itamambuca Mangrove, Ubatuba } & M & 14.8 & gonadal stages & Castiglioni \& Negreiros-Fransozo (2006c) \\
\hline & $\mathrm{F}$ & 12.1 & & \\
\hline Itaipu Lagoon, Niterói & $\mathrm{F}$ & 6.1 & smallest ovigerous female & This study \\
\hline
\end{tabular}

estimate fecundity. The obtained results can be influenced by this methodology because of to eggs loss during development. If only ovigerous females bearing eggs in the first stage were utilized, the average fecundity probably would be increased. On the other hand, the great majority of ovigerous females analyzed were in the first stage of development of their eggs. After hatching the eggs, the females probably go to the sediment surface and restart the foraging activities, getting energy to produce a new brood. Table VI illustrates the average fecundity of several species of $U c a$ in different localities.
The majority of terrestrial crabs display greater reproductive effort during the warmest months of the year. As mentioned before, it happens because temperature works as a catalytic agent, accelerating physiological mechanisms associated with gonadal development (Lima et al. 2006). The F' and the IIR values obtained for each season of the year in the present study corroborate this hypothesis, since both were larger in the summer and smaller in the winter.

Concerning egg size, their growth during embryonic development may be related to insufficient yolk reserve and to

Table VI. Average fecundity and carapace width range in several Uca species.

\begin{tabular}{|c|c|c|c|c|}
\hline Species & Locality & Average fecundity & $\begin{array}{l}\text { Carapace width } \\
\text { range }(\mathrm{mm})\end{array}$ & Author/year \\
\hline \multirow[t]{2}{*}{ U. inversa } & Sun Coast, Mozambique & 6192 & $10.3-20.1$ & Litulo (2005a) \\
\hline & $25^{\circ} 57^{\prime} \mathrm{S}, 32^{\circ} 35^{\prime} \mathrm{E}$ & & & \\
\hline \multirow[t]{2}{*}{ U. clorophthalmus } & Inhaca Island, Mozambique & 5506 & $10.0-19.4$ & Litulo (2006) \\
\hline & $26^{\circ} 00^{\prime} 17^{\prime \prime} \mathrm{S}, 32^{\circ} 54^{\prime} 52^{\prime \prime} \mathrm{E}$ & & & \\
\hline \multirow[t]{2}{*}{ U. thayeri } & Ceará, Brazil & 22066 & $18.5-26.5$ & BezerRa \& Matthews-Cascon (2007) \\
\hline & $01^{\circ} 03^{\prime} 46^{\prime \prime} \mathrm{S}, 46^{\circ} 46^{\prime} 22^{\prime \prime} \mathrm{W}$ & & & \\
\hline \multirow[t]{2}{*}{ U. uruguaiensys } & Ubatuba, São Paulo, Brazil & 1883 & $5.2-8.5$ & Costa et al. (2006) \\
\hline & $23^{\circ} 26^{\prime} 02^{\prime \prime} \mathrm{S}, 45^{\circ} 04^{\prime} 15^{\prime \prime} \mathrm{W}$ & & & \\
\hline \multirow[t]{2}{*}{ U. thayeri } & Ubatuba, São Paulo, Brazil & 31068 & $15.3-23.6$ & Costa et al. (2006) \\
\hline & $23^{\circ} 26^{\prime} 02^{\prime \prime} \mathrm{S}, 45^{\circ} 04^{\prime} 15^{\prime \prime} \mathrm{W}$ & & & \\
\hline \multirow[t]{2}{*}{ U. rapax } & Sebastian Inlet, Florida, USA & $5000-30000$ & 10.8-20.09 & Figueiredo et al. (2008) \\
\hline & $27^{\circ} 46^{\prime} 57^{\prime \prime} \mathrm{N}, 80^{\circ} 28^{\prime} 56^{\prime \prime} \mathrm{W}$ & & & \\
\hline \multirow[t]{2}{*}{ U. rapax } & Itaipu Lagoon, Niterói, Brazil & 4984 & $7.85-12.87$ & This study \\
\hline & $22^{\circ} 52^{\prime} 58^{\prime \prime} \mathrm{S}, 43^{\circ} 06^{\prime} 14^{\prime \prime} \mathrm{W}$ & & & \\
\hline
\end{tabular}


alterations due to high salinity levels in Itaipu Lagoon (GIMENEz \& ANGer 2001). Figueiredo et al. (2008) concluded that egg volume increasing during embryogenesis is correlated with the increase in egg water content, concluding that such increase during development was mainly due to water uptake by the embryo and/or retention of metabolic water from respiration. This author encountered eggs in U. rapax females ranging from 0.246 to $0.294 \mathrm{~mm}$, values closer to those observed in this study ( 0.20 to $0.28 \mathrm{~mm}$ ). The knowledge of egg size is important because it influences fecundity. Females that bear large eggs tends to show smaller fecundity than those that bear small eggs (Figueiredo et al. 2008). The predominance of the first embryonic phase in Itaipu females may have two different explanations, the first concerning the possibility of egg loss during the incubation period, due to desiccation and stress (Henmi 1989), and the second due to a slow embryonic development. The first hypothesis is more reasonable, given that slow embryonic development is normally associated to low salinity (Lima et al. 2006), a fact that differs from the conditions of Itaipu Lagoon.

In relation to the molt cycle, Costa \& Negreiros-Fransozo (1998) Callinectes danae Smith, 1869, Cobo \& Fransozo (2003) Goniopsis cruentata Latreille, 1803 and Castiglioni \& NegreirosFransozo (2006b) U. rapax, found that the highest molt activity occur in juvenile crabs and that the molt activity decreases after the puberty molt. This is probably related to the investment in the reproductive process, since the beginning of the reproductive activities lead to a decrease in the growth rate, especially the females that stop the growth when bearing eggs and, consequently, stop the molt activities (Crane 1975). The frequency of $U$. rapax in molt activity in Itaipu lagoon (26\%) is higher than those populations studied by CASTIGLIONI \& Negreiros-Fransozo (2006b) in Paraty coast, southward Itaipú lagoon (12.8\%). However, those differences could be attributed to sampling bias, since only the crabs conspicuous on the surface of the sediment were collected for those authors.

Some population and reproductive aspects of $U$. rapax population from Itaipu Lagoon, such as a male-biased sex ratio, low size, precocious maturity and low fecundity average, seem to be adaptations of the species to live in this environment. The existence of a continuous breeding season and juvenile recruitment in Itaipu Lagoon are evidences of the plasticity that enables $U$. rapax to live under diverse environmental conditions. The review about population and reproductive features provided herein and the results obtained from the studied population show that: a) these features are species-specific and also vary in relation to latitudinal range; b) the environmental conditions can be responsible for important changes among populations of the same species.

\section{ACKNOWLEDGEMENTS}

The authors are indebted to Marcos Tavares, from the Museu Paulista de Zoologia, for species identification, Carla Lima Torres Mendes for English review, and CAPES for provid- ing scholarship for the first author. The second author is in debt to CNPq for a Research Funding Fellowship and to FAPERJ for Research Grant (E-26/100.549/2007).

\section{LITERATURE CITED}

Ayres-Peres, L. \& F. mantelatto. 2008. Análise comparativa da estrutura populacional do ermitão endêmico do Atlântico Ocidental Loxopagurus loxochelis (Decapoda, Anomura) em duas regiões do Estado de São Paulo, Brasil. Iheringia, Série Zoologia, 98 (1): 28-35.

Bezerra, L.E.A. \& H. Matthews-Cascon. 2006. Population and reproductive biology of the fiddler crab Uca thayeri Rathbun, 1900 (Crustacea: Ocypodidae) in a tropical mangrove from northeast Brazil. Acta Oecologica 31 (3): 251-258.

Castiglioni, D.S. \& M.L. Negreiros-Fransozo. 2004. Comparative analysis of the relative growth of U. rapax (Smith) (Crustacea, Ocypodidae) from two mangroves in São Paulo, Brazil. Revista Brasileira de Zoologia 21 (1): 137-144.

Castiglioni, D.S. \& M.L. Negreiros-Fransozo. 2005. Comparative population biology of Uca rapax (Smith, 1870) (Brachyura, Ocypodidae) from Itamambuca and Ubatumirim mangroves in Ubatuba littoral, Brazil. Journal of Natural History 39 (19): 1627-1640.

Castiglioni, D.S. \& M.L. Negreiros-Fransozo. 2006a. Biologia populacional do caranguejo violinista Uca rapax (Smith, 1870) (Crustacea, Ocypodoidea), proveniente de uma área de manguezal degradado em Paraty, RJ, Brasil. Atlântica 28 (2): 73-86.

Castiglioni, D.S. \& M.L. Negreiros-Fransozo. 2006b. Ciclo reprodutivo do caranguejo Uca rapax (Smith) (Crustacea, Brachyura, Ocypodidae) habitante de um estuário degradado em Paraty, Rio de Janeiro, Brasil. Revista Brasileira de Zoologia 23 (2): 331-339.

Castiglioni, D.S. \& M.L. Negreiros-Fransozo. 2006c. Physiologic sexual maturity of the Fiddler Crab Uca rapax (Smith, 1870) (Crustacea, Ocypodidae) from two mangroves in Ubatuba, Brazil. Brazilian Archives of Biology and Technology 49 (2): 239-248.

Castiglioni, D.S.; M.L. Negreiros-Fransozo; L.S.L. Greco; A.F. Silveira \& S.O. Silveira. 2008. Gonad development in females of fiddler crab Uca rapax (Crustacea, Brachyura, Ocypodidae) using macro and microscopic techniques. Iheringia, Série Zoologia, 97 (4): 505-510.

Сoвo, V. \& J.A. Fransozo. 2003. External factors determining breeding season in the red mangrove crab Goniopsis cruentata (Latreille) (Crustacea, Brachyura, Grapsidae) on the São Paulo State northern coast, Brazil. Revista Brasileira de Zoologia 20: 213-217.

Colby, D.R. \& M.S. Fonseca. 1984. Population dynamics and somatic growth of the sand fiddler crab Uca pugilator. Marine Ecology Progress Series 16 (3): 269-279.

Colpo, K.D. \& M.L. Negreiros-Fransozo. 2003. Reproductive output of Uca vocator (Herbst, 1804) (Brachyura, Ocypodidae) 
from three subtropical mangroves in Brazil. Crustaceana 76 (1): 1-11.

Costa, M.C. \& M.L Negreiros-Fransozo. 1998. The reproductive cycle of Callinectes danae Smith, 1869 (Decapoda, Portunidae) in the Ubatuba region, Brazil. Crustaceana 71 (6): 615-627.

Costa, T.M.; S.M.J. Silva \& M.L. Negreiros-Fransozo. 2006. Reproductive pattern comparison of Uca thayeri Rathbun, 1900 and U. uruguayensis Nobili, 1901 (Crustacea, Decapoda, Ocypodidae). Brazilian Archives of Biology and Technology 49 (1): 117-123.

Crane, J. 1975. Fiddler crabs of the world. Ocypodidade: Genus Uca. Princeton, Princeton University Press, 736p.

Díaz, H.; J.E. Conde \& M. Belavilacqua. 1983. A volumetric method for estimating fecundity in Decapoda. Marine Ecology 10: 203-206.

Emmerson, W.D. 1994. Seasonal breeding cycles and sex ratios of eight species of crabs from Mgazana estuary in Transkei, Southern Africa. Journal of Crustacean Biology 14 (3): 568578.

Figueiredo, J.; G. Penha-Lopes; J. Anto; L. Narciso \& J. Lin. 2008. Potential fertility and egg development (volume, water lipid and fatty acid content) through embryogenesis of Uca rapax (Decapoda, Brachyura, Ocypodidae). Journal of Crustacean Biology 28 (3): 528-523.

GeISEL, J.T. 1972. Sex ratio, rate of evolution and environmental heterogeneity. American Naturlist 106: 380-387.

Genoni, G.P. 1985. Food limitation in salt marsh fiddler crab Uca rapax (Smith) (Decapoda, Ocypodidae). Journal of Experimental Marine Biology and Ecology 87: 97-100.

GeNONI, G.P. 1991. Increased burrowing by fiddler crabs Uca rapax (Smith) (Decapoda: Ocypodidae) in response to low supply. Journal of Experimental Marine Biology and Ecology 147: 267-285.

Giménez, L. \& K. Anger. 2001. Relationships among salinity, egg size, embryonic development, and biomass in the estuarine crab Chasmagnatus granulata Dana, 1851. Journal of Experimental Marine Biology and Ecology 260: 241-257.

GreENSPAN, B.N. 1980. Male size and the reproductive success in the communal courtship system of the fiddler crab Uca rapax. Animal Behavior 28: 387-392.

Hartnoll, R.G. 1985. Growth, sexual maturity and reproductive output. Crustacean Issues 3: 101-128.

Hartnoll, R.G. \& P. Gould. 1988. Brachyuran life history strategies and the optimization of egg production. Proceeding of the Zoological Simposium 59: 1-9.

Hattoti, G.Y. \& M.A.A. Pinheiro. 2003. Fertilidade do caranguejo de mangue Ucides cordatus (Linnaeus) (Crustacea, Brachyura, Ocypodidae), em Iguape (São Paulo, Brasil). Revista Brasileira de Zoologia 20 (2): 309-313.

Henmi, Y. 1989. Life-history patterns in two forms of Macrophtalmus japonicus (Crustacea: Brachyura). Marine Biology 101: 53-60.
Henmi, Y. 2003. Trade-off between brood size and brood interval and the evolution of underground incubation in three fiddler crabs (Uca perplexa, U. vocans, and U. dussumieri). Journal of Crustacean Biology 23 (1): 46-54.

Hines, A.H. 1982. Allometric Constraints and Variables of Reproductive Effort in Brachyuran Crabs. Marine Biology 69: 309-320.

KJerfye, B. \& B. Knoppers. 1999. Physical Characteristics of lagoons of the East Fluminense Coast, State of Rio de Janeiro, Brazil. Environmental Geochemistry of Coastal Lagoon Systems 6: 57-67.

Koch, V.; Wolff \& K. Diele. 2005. Comparative population dynamics of four fiddler crabs (Ocypodidae, genus Uca) from a North Brazilian mangrove ecosystem. Marine Ecology Progress Series 291: 177-188.

LEME, M.A. 2006. Seasonal changes in the reproductive traits of the crab Sesarma rectum (Grapsoidea: Sesarmidae) on the northern coast of São Paulo state, Brazil. Journal of Crustacean Biology 26 (2): 141-147.

Lima, G.V.; M.R.S. SoARES \& L.M.Y. Oshiro. 2006. Reproductive biology of the sesarmid crab Armases rubripes (Decapoda, Brachyura) from an estuarine area of the Sahy River, Sepetiba Bay, Rio de Janeiro, Brasil. Iheringia, Série Zoologia, 96 (1): 47-52.

LiTULO, C. 2004. Reproductive aspects of a tropical population of the fiddler crab Uca annulipes (Brachyura: Ocypodidae) at Costa do Sol Mangrove, Maputo Bay, southern Mozambique. Hydrobiologia 525: 167-173.

Litulo, C. 2005a. Population biology of the fiddler crab Uca annulipes (Brachyura, Ocypodidae) in a tropical east African mangrove (Mozambique). Estuarine, Coastal and Shelf Science 62: 283-290.

Litulo, C. 2005b. Population structure and reproductive biology of the fiddler crab Uca inversa (Hoffman, 1874) (Brachyura: Ocypodidae). Acta Oecologica 27: 135-141.

Litulo, C. 2006. Population and reproductive biology of the fiddler crab Uca chlorophtalmus (Brachyura: Ocypodidae) from Inhaca, southern Mozambique. Journal of the Marine Biological Association of the United Kingdom 86: 737742.

MASUnARI, S. 2006. Distribuição e abundância dos caranguejos Uca Leach (Crustacea, Decapoda, Ocypodidae) na Baía de Guaratuba, Paraná, Brasil. Revista Brasileira de Zoologia 23 (4): 901-914.

Masunari, S. \& B.P. Swiech-Ayoub. 2003. Crescimento relativo em Uca leptodactyla Rathbun (Crustacea, Decapoda, Ocypodidae). Revista Brasileira de Zoologia 20 (3): 487491.

McNamara, J.C. \& G.S. Moreira. 1983. Ultrastructure of chromatophores from the fiddler crabs Uca rapax (Smith) and Uca uruguayensis (Nobili) (Decapoda, Brachyura). Crustaceana 44: 301-309.

Melo, G.A.S. 1996. Manual de identificação dos Brachyura 
(caranguejos e siris) do litoral brasileiro. São Paulo, Plêiade, FAPESP, 604p.

Mohktari, M.; A. Savari; H. Rezai; P. Kochanian \& A. BitaAb. 2008. Population ecology of fiddler crab, Uca lactea annulipes (Decapoda, Ocypodidae) in sirik mangrove estuary, Iran. Estuarine, Coastal and Shelf Science 76: 273-281.

Muiño, R.; L. Fernández; E. GonzÁlez-Gurriarrán; J. Freire \& A. Vilar. 1999. Size at maturity of Liocarcinus depurator (Brachyura: Portunidae): a reproductive and morphometrtic study. Journal of the Marine Biological Association of the United Kingdom 79: 295-393.

Pinheiro, M.A.A. \& O.S.L. Terceiro. 2000. Fecundity and the reproductive output of the speckled swimming crab Aranaeus cribrarius (Lamarck, 1818) (Brachyura, Portunidae). Crustaceana 73 (9): 1121-1137.

Rodriguez, A.; P. Drake \& M.A. Arias. 1997. Reproductive periods and larval abundance patterns of the crabs Panopeus africanus and Uca tangeri in a shallow inlet (SW Spain). Marine Ecology Progress Series 149: 133-142.

SAlmon, M. 1971. Signal characteristics and acoustic detection by fiddler crabs, Uca rapax and Uca pugilator. Physiological Zoology 44 (4): 210-221.

SALMON, M. 1987. On the reproductive behavior of the fiddler crab Uca thayeri, with comparisons to U. pugilator and $U$. vocans: evidence for behavioral convergence. Journal of Crustacean Biology 7 (1): 25-44.

SAlmon, M. \& M.K. KetTler. 1987. The importance of behavioral and biochemical differences between fiddler crab taxa, with special reference to Uca rapax (Smith) and $U$. virens (Salmon and Atsaides). Contributions in Marine Science 30: 63-76.

SASTRY, A.N. 1983. Ecological aspects of reproduction, p. 179270. In: V.J. Vernberg \& W.B. Vernberg (Eds). The Biology of Crustacea. New York, Academic Press, vol. 8, 383p.

SpIVAK, E.D.; M.A.Gavio \& C.E. Navarro. 1991. Life history and structure of the world's southernmost Uca population: Uca uruguayensis (Crustacea, Brachyura) in Mar Chiquita Lagoon (Argentina). Bulletin of Marine Science 48 (3): 679-688.

TEAL, J.M. 1958. Distribution of the fiddler crabs in Georgia salt marshes. Ecology 39: 185-193.

Thorson, G. 1950. Reproductive and larval ecology of marine bottom invertebrates. Biological Reviews 25 (1): 1-45.

VernberG, F.J. 1959. Studies on the physiological variation between tropical and temperate zone fiddler crabs of the genus Uca. II. Oxygen consumption of whole organisms. The Biological Bulletin 117: 163-184.

Werner, A.M. 1972. Sex ratio as a function of size in marine crustacea. American Naturalist 106: 321-350.

ZANDERS, I.P. \& W.E. RoJas. 1996a. Transbranchial potentials and ion fluxes across isolated, perfused gills of Uca rapax. Marine Biology 125: 307-314.

ZANDERS, I.P. \& W.E. RoJAs. 1996b. Osmotic on ionic regulation in the fiddler crab Uca rapax acclimated to dilute and hypersaline seawater. Marine Biology 125: 315-320.

Zanders, I.P. \& W.E. RoJas. 1996c. Salinity effects on cadmium accumulation in various tissues of the tropical fiddler crab Uca rapax. Environmental pollution 96 (3): 293-299.

Submitted: 11.II.2009; Accepted: 11.XII.2009.

Editorial responsibility: Maria Lúcia Negreiros-Fransozo 